\title{
DOUBLE INVOICING IN INTERNATIONAL TRADE: THE FRAUD AND NULLITY EXCEPTIONS IN LETTERS OF CREDIT - ARE THE AMERICA ACCORD AND THE UCP 500 CROOKS' CHARTERS!?*
}

\author{
Ademun-Odeke **
}

\section{ABSTRACT}

This article: First, (a) re-examines the fraud exception rule in letters of credit transactions with specific reference to the United City Merchants $\mathrm{v}$ Royal Bank of Canada (the American Accord) and against the background of a recent commonwealth decision accepting nullity as a new exception; (b) evaluates its impact on over/under invoicing under the WTO Agreement on Pre-shipment Inspection of Goods in International Trade (PSI); and (c) assesses its implication on the IMF Agreement on Exchange Control implemented in the UK by the IMF Agreement Regulations 1946 made under the IMF Agreement Acts 1945 as amended. Secondly, it argues that the current UCP 500 is outmoded and inadequate to meet current needs and is therefore in need of urgent revision. Thirdly, it recommends, inter alia, that in accordance with the said commonwealth decision, fraud by third parties should be recognised by English law as an independent and separate nullity exception. Fourth, and finally, it concludes that the status-quo acts as an unwitting Crooks' Charter for money launderers, documentary fraudsters and other white collar crimes.

\section{INTRODUCTION}

The House of Lords delivered a landmark judgement in 1982 which did attract the notice it deserves but was later to have a profound effect on the letter of credit jurisprudence. Although there had been a number of English and world decisions on the subject especially in the 1970s, no case also demonstrates the development and reasons for over invoicing in international trade as did the American Accord. ${ }^{1}$ The case dealt with many aspects of letters

\footnotetext{
* The author is grateful to Professor Roy Goode of the University of Oxford, Professor Charles Debattista of the University of Southampton and Professor John Carter of the University of Sidney for reading through earlier the draft of this article and making valuable comments. However the author bears ultimate responsibilities for views held and any short-comings herein.

** LLB; LLM; PhD; MIEx; COMPANION NI. Bournemouth Law School, Institute of Business and Law, University of Bournemouth.
} 
of credit, the principle means of payments in international trade. Little over a decade later (1994), the WTO finalised the Agreement on Preshipment Inspection of Goods in International Trade (PSI). ${ }^{2}$ An essential aspect of the PSI Agreement is prevention of double- and under invoicing. Although English courts are familiar with PSI and experienced in dealing with fraud exception and exchange control regulation cases, this was the first time all three had been subject of an English court decision.

The case is important for other reasons too. First, and hitherto, courts had dealt with fraud committed by the sellers and/or their agents and assignees but not by third parties. Secondly, the case came at an opportune time when the international finance community was grappling with the menace of money laundering, documentary frauds and other white collar crimes. Thirdly, although earlier attempts in English courts had failed, ${ }^{3}$ there has ever-since been a Commonwealth decision ${ }^{4}$ that has accepted nullity as a separate and independent exception in addition to fraud exception.

The aim of this article is, therefore, seven folds: First, to re-examine the House of Lords' decision in the American Accord and to reassess English law on fraud exception. The article argues that the Court Appeal's decision, reversed by the House of Lords, was the correct one. Secondly, to postulate

${ }^{1}$ United City Merchants (Investments) Ltd and others $v$ Royal bank of Canada (Vitrorefuerzos SA and others, third parties) [1981] 3 All ER 142 (Court of Appeal); and United Merchants (Investments) Ltd and others v Royal Bank of Canada and others [1982] 2 All ER 720 (House of Lords); for annotation of the case see The Digest (Annotated British, Commonwealth and European Cases), $2^{\text {nd }}$ Reissue Vol 39(3) para 5251 at pp 535-536;

${ }^{2}$ For the Agreement on Pre-shipment Inspection of Goods in International Trade See, The WTO Uruguay Round Agreements, Agreement Establishing the WTO signed in Marrakesh, 1994, Annex 1A, Multilateral Agreements on Trade in Goods, Preshipment Inspection.

${ }^{3}$ See eg the Court of Appeal case of Montrod Ltd v Grundkotter Fleischvertriebes GmbH and Another [2002] 1 ALL ER (Commercial) 257, CA; and Czarnikow-Rionda Sugar Trading Inc. $v$ Standard Bank of London Ltd and Others [1999] 1 All ER 890 (Commercial); Current Law Yearbook, Sweet and Maxwell Vol1999(1) para 279 p 80 where Rix J's approach was to look at the balance of convenience at to which innocent party , the confirming bank or the applicant, would suffer most and/or irreversibly if the injunctions was upheld or discharged. The judge came down, heavily in support of the principle that the court should interpret its right intervene in cases of fraud restrictively and discharged the injunction; and Banco Santander SA v Bayfern Ltd [199] 2 All EER 18 where Langely J, having considered the American Accord at length took the view that once a fraud has been committed the court would intervene even if this meant penalising the innocent confirming bank than the fraudster.

${ }^{4}$ See the Singapore Supreme Court case of Beam Technologies $v$ Standard Chartered Bank [2003] 1SLR 597 
whether, if decided post WTO PSI Agreement, the decision on over-invoicing and under-invoicing would have been different. Thirdly, to analyse the significance of the American Accord decision on international efforts to combat money laundering and other documentary crimes in international trade law in the wake of recent upsurges in that practice, without which, the article suggests that the UCP 500 generally and the American Accord, in particular would be crooks' charters. Fourth, to demonstrate that decisions before and after the American Accord were motivated by policy rather than purely legal considerations. Fifth, to re-examine the fraud exception principle and to put forward new suggestions that, as a matter of common law, courts should include nullity exception to cover fraud committed by third parties with or without the knowledge of sellers and/or beneficiaries. Sixth, to recommend amendments to the next revision of the UCP to include, inter alia, provisions on nullity or any fraud and/or related exceptions, arbitration and applicable law clauses so as to balance the interests of all parties. Seventh, and finally, to provide an exhaustive commentary on the case, with a view to furtherance of knowledge, that the important American Accord decision deserves. In this respect the article argues that attempt was long overdue.

The article is divided as listed below. Following the introduction and establishment of the foundation in Parts I and II, the main thrust of the analysis is contained in Parts III-V which discuss various aspects of the case and Part VI which envisages domestic and international implications of the decision.

\section{THE “AMERICAN ACCORD” AND THE FRAUD EXCEPTION}

\section{(a) Summary of the Facts}

The summary of the facts in the case is that an English company sold a glass fibre plant to a Peruvian buyer. Payment was arranged under an irrevocable documentary letter of credit issued by Banco Continental SA (issuing bank) and confirmed by the Royal Bank of Canada at its London branch (the confirming bank). The credit was subject to the 1974 Revision of the UCP (UCP 400). ${ }^{5}$ Payment arrangements agreed between the seller and the buyer involved inflating ("over invoicing” or "double invoicing") purchase price in order to enable the buyer to transfer and hold the proceeds in a Miami bank in breach of the Peruvian Exchange Control Regulations.

The seller assigned to the appellant their rights under the credit. Payment under the credit was to be by sight drafts on the issuing bank against delivery inter alia of a full set of "on board" bills of lading evidencing shipment of the

\footnotetext{
${ }^{5}$ Publication No 411, now superseded by the UCP 500. The UCP were first published by the ICC 1933 with revised versions issued in 1951, 1962, 1974 and 1983.
} 


\section{THE DENNING LAW JOURNAL}

goods on or before 15 December 1976. The actual shipment was, in fact, made on the American Accord instead of on the American Adventure, a day later on 16 December 1976 and from the port of Felixstowe instead of London. The date of 16 December 1976 on the original bills of lading was visibly altered by a shipping clerk to15 December 1976. The documents were rejected by the confirming bank. Subsequently, the tender was withdrawn, corrections made and fresh bills of lading tendered, bearing notation ${ }^{6}$ to the effect that the goods were actually on board on 15 December. The bank still refused to honour the credit pleading fraud. The beneficiaries sued.

The trial judge, Mocatta $\mathrm{J}^{7}$ held that the bank had wrongly refused to honour the credit, since the fraud was not committed by or with the knowledge of the sellers or the beneficiaries (assignee bank) but by a third party. He reserved his judgment on the double invoicing (monetary transaction). The effect of the ruling being that the bank would have to honour the credit despite having knowledge of fraud. The bank appealed and the Court of Appeal, ${ }^{8}$ Stephenson LJ, (Ackner LJ and Griffiths LJ, concurring), held (reversing the decision of the trial court) that the bank was entitled and in fact under an obligation to reject the documents if fraud was established. The court reasoned that if a document which was false in the sense that it was forged by a person other than a beneficiary could entitle the bank to refuse payment, there was no reason why a document in any way false to the knowledge of such a person should not have the same effect. The appellate ruling went against the grain of the then-established law that in letters of credit $^{9}$ and performance bonds, ${ }^{10}$ unless the seller is aware or fraud is proved the bank should honour its obligations on credit. The beneficiaries appealed to the House of Lords.

The House of Lords, ${ }^{11}$ Diplock LJ (Russell LJ, Scarman LJ and Bridge LJ, concurring) reversed the Court of Appeal's decision and reinstated in part Mocatta's judgement. The House of Lords' judgment was delivered by Diplock LJ, like Mocatta, an experienced commercial judge. Their Lordships held that the confirming bank's duty to the seller was only vitiated if there was fraud on the seller's part, and the bank remained under a duty to pay, even if the documents presented, although conforming on their face to the terms of the

\footnotetext{
${ }^{6}$ Notation is the process of certifying, normally by signature or signature a "received for shipment" bill of lading after the goods have been loaded or amending and retendering the bill lading following a rejection of the first tender of documents.

${ }^{7}$ [1979] 1 Lloyds Rep 267.

${ }^{8}$ [1981] 2 All ER 142.

${ }^{9}$ Letters of Credit includes standby letters of credit where they are incorporated into the text of the credit as used in practice in the USA.

${ }^{10}$ Performance Bonds are treated the same way as bills of lading regarding the fraud exception.

${ }^{11}$ [1982] 2 All ER 720.
} 


\section{THE DENNING LAW JOURNAL}

credit, nevertheless contained a statement of material fact that was not accurate and known to the bank. Curiously, the consequence of the decision was that the bank was not relieved from liability even if the documents contained a material representation of fact which the person issuing the documents knew to be false and which was intended by him to deceive persons, including the seller himself, who might deal in the documents thereafter.

The case is significant in many ways in restating the common law position on: fraud exceptions; currency exchange controls in international trade; severability in contracts; equitable doctrine approach in judicial decisions; and more importantly role of under-invoicing and over-invoicing using letters of credit in international trade-the subject matters of this article.

\section{(b) On the Fraud Exception Jurisprudence}

\section{(i) Autonomy of documents and credits}

Both the trial court and the House of Lords based their judgments for the claimants on the independence of the documents and therefore the credits. The reasoning being that "credits by their nature are separate transactions from the sales or other contracts on which they may be based and banks are in no way concerned with or bound by such contracts." 12 This is because, "In documentary credit operations all parties are concerned deal in documents and not in goods," 13 a position endorsed by Jenkins LJ in Mallas (t/a Hamza Mallas \& Sons) $v$ British Imex Industries $L t d^{14}$ and a case referred to in the American Accord ruling and in which the court ruled it was clear from the provisions ${ }^{15}$ that the opening of a confirmed credit imposes upon a banker an absolute obligation to pay, irrespective of any dispute there may be between the parties whether the goods are up to contract or not. ${ }^{16}$

One is not taking issue with the House of Lord's ruling in the American Accord per se as it is within settled law and, as will be apparent below, there is rationale for such positions. The thesis of this article is, however, that courts have over-emphasised the independence of the credit in favour of the seller and other beneficiaries' often to the detriment of the buyer and the issuing bank. We shall return to that later. Although conceding to case law, and authors who accept that position dogmatically, that there is need to balance competing interests of parties to the sales and credit contracts, this author begs to differ.

\footnotetext{
${ }^{12}$ Uniform Customs and Practice for Documentary Credits (UCP) of the ICC 1974 Revision , ICC Publication No 290 Art 8(a) now Art 3 of the UCP 500.

${ }^{13}$ Ibid Art 8(b).

${ }^{14}$ [1958] 1 All ER 262, (sometimes spelt as Hamzeh Malas).

${ }^{15}$ Now Art 15 of the UCP 500.

${ }^{16}$ [1958] 2 QB 127 at 129.
} 


\section{THE DENNING LAW JOURNAL}

The author is further persuaded by Hooley, ${ }^{17}$ who, after setting out the autonomy principle in the UCP and examining whether fraud exception applies to fraud in the underlying transaction, considers whether, where fraud on the part of the beneficiary cannot be proved, payment can be withheld by the confirming bank on the basis that the forged fraudulent document is a nullity. In the process he criticises the Court of Appeal's recent decision in Montrod Ltd $v$ Grundkotter, in which the existence of a nullity exception, as accepted by the Singapore Supreme Court decision in Beam Technologies $v$ Standard Chartered Bank, ${ }^{18}$ was rejected. The American Accord was cited extensively and distinguished in Beam Technologies but followed in Montrod Ltd v Grundkotter which denied the existence of the nullity exception under English common law.

On the premise that the autonomy principle lends itself to abuse one author commented that, "There are many means that are available to criminal syndicates to launder their illegal gains. Letters of credit transactions, in my view, are an ideal vehicle for laundering illicit funds and have so far attracted little attention from the regulatory authorities. While in every other service provided by banks, under the anti-money laundering statutes, bankers are required by the law to comply with 'know your customer' regulations, bankers in documentary credits department remain consistent with the documentary and independent principle." ${ }^{\prime 9}$ It is, therefore, not far-fetched to suggest that the principle and its application as fraud exception in the American Accord, and authorities before and after it, provides comfort to fraudsters and is appropriately referred to as the Crooks Charter. It is a further argument of this article that the autonomy principle neglects not only the opposing doctrine of strict compliance but also the interest of other innocent parties.

\section{(ii) And the Doctrine of Strict Documentary Compliance and the UCP}

This article further reiterates that the American Accord was at variance with the doctrine of strict documentary compliance applicable to the UCP and credit. Even if the beneficiary's claim would have succeeded on the basis of the autonomy principle, it is submitted that it should still have failed on the doctrine of strict documentary compliance. The doctrine provides that the beneficiary should present the exact documents and in the terms and conditions required. The documents must conform strictly to the terms of the credit; and

${ }^{17}$ Hooley, RJA, Fraud and Letters of Credit: Part 1- Butterworth Journal of International Banking Law \& Finance (BJ I B\&F), 2003, Vol 18 No 3 pp 91-98; see also [2002] CLJ 281.

${ }^{18}$ [2003] 1 SLR 597.

19 Anonymous Author, "Money laundering and documentary credit transactions", Journal of Money Laundering Control, 2002, Vol 5 No 3 p 217. 
"there is no room for documents which are almost the same or which will do just as well., ${ }^{20}$ Only then should we move to the point that if the documents conform with the terms of the credit, the banker is not concerned as to whether the documents stipulated by the buyer serve any useful commercial purpose or as to why the customer called for tender of a document or a particular description $^{21}$ or as to the legal effect of the document or vis a vis the applicant. $^{22}$ It forms no part of the bank's function, when considering whether to pay against the documents presented to it, to speculate about the underlying facts. ${ }^{23}$ Neither should the bank question the usefulness or sufficiency of the documents. $^{24}$

Nevertheless, as in the American Accord, where the credit calls for shipping documents, they must conform to customary shipping documents as to be reasonably fit to pass current in commerce. Even given that the requirements of strictly compliance are slightly different, the American Accord tender was still an improper and un-conforming tender. The bill of lading had a wrong shipping date, it was deliberately altered, almost same as forged, and the issuing bank, the seller and the beneficiaries were all aware of it. The tender and acceptance of forged documents in this case went against the grain of established and accepted case law that a tender of documents which, properly read and understood, call for further inquiry or are such as to invite litigation is clearly a bad tender. ${ }^{25}$ Accordingly a beneficiary who presents fraudulent documents has not complied with the requirement and should therefore fail. This was not a tender in the legal sense of the term. The beneficiary failed to do so in the present case and should not have succeeded.

(iii) Effect Fraud on the bank's guarantee under the credits.

It is argued that fraud from whatever source should nullify the guarantee provided by the bank guarantee. ${ }^{26}$ Instead the American Accord simply stuck to

${ }^{20}$ Equitable Trust Co of New York v Dawson Partners (1926) 27 Ll LRep 49 at p 52, per Lord Sumner.

${ }^{21}$ Kydon Compania Naviera SA v National Westminster Bank [1981] 1 Lloyd's Rep 68 at 75 .

${ }^{22}$ British Imex Industries Ltd v Midlands Bank Ltd [1958] 1 All ER 264, which was cited in the Court of Appeal's judgment.

${ }^{23}$ Westpac Banking Corporation and Commonwealth Steel Co. Ltd v South Carolina National Bank [1986] 1 Lloyds Rep 311 at 315, PC.

${ }^{24}$ See Article 15 of the UCP.

${ }^{25}$ See Hansson $v$ Hemel and Horley Ltd [1922] 2 AC 36 at 46, and M.Golodetz \& Co Inc v Czarnikow-Rionda Co Inc (The Galatia) [1979] 2 All ER 726 at 739-740, per Donaldson J(affirmed [1980] 1 All ER 501).

${ }^{26}$ For liability of forged documents and for the scope of the fraud $\backslash$ exception, see Halsbury' Laws of England, Vol 3 (1), 4th edn, paras 286 and 289. 


\section{THE DENNING LAW JOURNAL}

the hitherto common law and international commercial principles on fraud exception in credits and performance bond ${ }^{27}$ transactions, namely that unless the bank is aware or has knowledge of the fraud it will pay on the letter of credit. But it was conceded that the bank was both aware and had knowledge. The modern origin of this principle is the American case of Edward Sztejn v $J$ Henry Schroder Banking Corporation, ${ }^{28}$ cited and referred to in the American Accord judgment and which has been followed by English judges in such landmark decisions as Bank Russo-Iran v Gordon Woodroffe \& Co Ltd, ${ }^{29} R$ Harbottle (Mercantile) Ltd $v$ National Westminster Bank Ltd, ${ }^{30}$ and Edward Owen Engineering Ltd $v$ Barclays Bank International. ${ }^{31}$ In Edward Owen Engineering, Geoffrey Lane LJ summarised the position thus: "The only circumstances which would justify the bank not complying with a demand made under that agreement would be those which would exonerate them under similar circumstances if they had entered into a letter of credit, and that is this, if it had been clear and obvious to the bank that the buyers had been guilty of the offence."32

On this point, once again, one has no basic quarrels with Lane LJ's decision as it simply restated accepted law. It is submitted, however, that in the American Accord, both the trial court and the House of Lords got it wrong in allowing the payment and the Court of Appeal was correct in rejecting the payment for the reasons given above. The trial court and the House of Lords limited their interpretation of the fraud exception only to when it emanates from the seller or his agent. When there is fraud from third party sources, as in this case, the courts having accepted that they were in new territory should have been flexible, bold and prepared to distinguish earlier authorities and to break new grounds as the Singapore Court was to do later in Beams Technologies.

Secondly, English courts were not prepared to exercise judicial oversight by considering other issues, such as the surrounding circumstances and their overall effect of the case. In this the courts are not alone; most academic authors tend to peddle that common ground. This author, with due respect, begs to differ. In addition to Hooley ${ }^{33}$ other authors such as Chin LY and Wang YK

\footnotetext{
${ }^{27}$ Performance bonds are treated the same way as letters of credit with regard to fraud, see generally, Quentin Loh mad Tang Hang Wu "Injunctions Restricting Calls on Performance Bonds-Is fraud the only ground in Singapore?”, Lloyds Maritime \& Commercial Law Quarterly, 2000, 348-363.

${ }^{28}$ (1941) 31 NYS 2n 631.

29 (1972) Transcript, The Times, October 4.

${ }^{30}$ [1977] 2 All ER 862 at 870 per Kerr J.

31 [1978] 1 All ER 976.

32 [1978] 1 All ER 976 at 986 per Lord Denning MR.

33 See, Note 17, supra.
} 


\section{THE DENNING LAW JOURNAL}

who $^{34}$ take the same position in their analysis of the Singapore court decision in Beam Technologies on whether a bank could refuse to pay on a documentary credit, even though the beneficiary presenting the documents was not guilty of fraud, because the documents were forgeries perpetrated by a third party. They also review case law on the autonomy of documentary credits and examine the implications for international trade if the Commonwealth jurisdictions followed the Singaporean ruling and allowed an exception to the autonomy principle, based on the nullity of the documents. Having followed the American decision on Sztejn it is hoped they will do likewise with a common law decision.

That leads to the issue of fraud committed by the seller or his agent.

\section{(iv) Fraud committed by the seller or his agent}

The American Accord and other cases on the subject suggest for the buyer and his bank to succeed they have to prove that the fraud has been committed by either the seller or his agent or any one else instructed by him. Although the contrary view was not argued before them the trial court and the House of Lords limited themselves only to fraud committed by the seller or his agent. They were not prepared to look at fraud, although committed by a third party, affecting the whole transaction. Instead they preferred not to express any opinions and to leave the matter open. ${ }^{35}$ Although the seller and the assignee in the American Accord were not parties to the fraud they nevertheless benefited from it. That in itself should not be a consideration, nevertheless where as in this case, the seller not only knew of the first fraud (bill of lading) but also willingly participated in the second fraud (double-invoicing), he should not have been permitted to benefit. The seller was not entirely innocent in this respect. They went along with the buyer's scheme of using the credit for purposes other than paying for goods bought and shipped.

It is submitted that in such cases, the House of Lords, like the Court of Appeal should have been prepared to look at the whole transaction. Fraud is fraud and it makes no difference who in the credit chain perpetrates it. After all

${ }^{34}$ Chin LY and Wang YK, “Autonomy-a Nullity at last?” LM\&CLQ (2004) No1 February pp 14-19; see also Quentin Loh and Tang Hang Wu, "Injunctions Restraining Calls on Performance Bonds- Is fraud the only ground in Singapore?” LM \& CLQ (2000) pp 348-363.

${ }^{35}$ Hence Lane LJ's statement, “ There is I think it is conceded, no authority , English or American , directly deciding that the fraud of a third party such as the maker of a false document is or is not a good defence to a claim to be paid in accordance with the terms of a letter of credit. Most of these cases of fraud are, as is to be expected, cases of fraud by a seller hoping to be paid for rubbish or, at the least, defective goods before the true state of affairs are known which his own misdescription has concealed." [1981] 3 All ER 142 at 161. 


\section{THE DENNING LAW JOURNAL}

the bank is at risk regardless of who commits the fraud. Where it fails the beneficiary the bank is normally penalised, why shouldn't the seller be penalised when it fails the bank? The bank takes on this onerous duty on the basis that others will perform their duties and do so honestly. The seller and the beneficiary fell short on this occasion, and in failing to recognise, these courts too failed in their responsibilities to protect all parties to the contract.

All cases cited before the court dealt with fraud on the seller's part and included cases where no goods were delivered at all. Previous decisions did not make distinctions between the frauds. The American Accord was however different from that scenario and should have been distinguishable: it involved fraud from and by a third party. Having conceded (see below) that there were no authorities for fraud other than that committed by the seller, the courts should have been free to act independently rather than feeling bound by distinguishable precedence. They (trial court and House of Lords) should have considered that what matters is the existence and effect of the fraud irrespective of source. They should also have borne in mind that once the seller benefits (even if they are not party to the fraud) that is what counts. For those reasons courts should extend the exception to fraud if committed by third parties with or without the seller's knowledge and/or consent. Hence the nullity exception.

(v) Fraud committed by a third party with or without sellers or beneficiary's knowledge-the Nullity Exception.

In the American Accord, fraud was committed by a third party without the seller or assignees knowledge. The trial court and the House of Lords were heavily influenced by that fact, hence Stephenson LJ's statement that;

"There is, I think conceded, no authority, English or American, directly deciding that the fraud of a third party such as the maker of a false document is or is not a good defence to a claim to be paid in accordance with the terms of a letter of credit. Most of the cases of fraud are, as is to be expected, cases of fraud by the seller hoping to be paid for rubbish or, at the least, defective goods before the true state of affairs which his own description has concealed. It is in the context of such facts that Bailhache J's statement about description, fraudulent or (where the buyer had rejected the goods before payment by the bank) innocent, in Society Metallurgique d' Audbrives \& Villerupt $v$ British Bank for Foreign Trade ${ }^{36}$ and the

${ }^{36}$ (1922) 11 Ll L Rep 168 at 170. 
statements quoted from Edward Owen Engineering Ltd $v$ Barclays Bank have to be considered.”37

Secondly, the two courts were influenced by the fact that the fraud was committed unknown to the sellers or beneficiaries. However, as has been constantly argued, as far as credit dealings are concerned it should not make any difference who commits the fraud. What matters is that fraud is committed and that when presented for payment the documents do not conform. Unless this position is adopted the process puts the banks in jeopardy and makes a mockery of the system. If they do not pay they are crucified by the beneficiary and the courts. If they do pay despite the fraud they are crucified by the buyer and his banks (issuing, corresponding, confirming and paying). Tails they lose heads they do not win.

Most academic authors cited by the Court of Appeal such as Davis, ${ }^{38}$ Gutteridge and Megrah ${ }^{39}$ and Benjamin ${ }^{40}$ tend to follow the status quo. To this should be added the American Accord, Montrode, Equitable Trust and Dawson, Gian Singh \& Co Ltd v Banque de L'Indochine ${ }^{41}$ and related decisions for the status quo. The only exceptions are Hooley above who give clear support to the exception including the fraud of third party and Goode ${ }^{42}$ who disputes the protection accorded holders in due course such as in the American Accord and criticised Mocatta J's decision for holding that the loading supervisor's fraud did not defeat their claim. Goode also cites the American case of United Technologies Corporation $v$ Citibank $N A^{43}$ (one of the cases which applied New York's UCC), for his position. This club of 'dissenters' include Chin and Wang. ${ }^{44}$ To this should be added Justice Chao

${ }^{37}$ [1981] 1 All ER 142 at 161.

${ }^{38}$ The Law Relating to Commercial Letters of Credit, 3rd, Edn,1963, pp 145-1460], Gutteridge and Megrah [Laws of Bankers Commercial Credits 6th Edn, 1979, p 137.

${ }^{39}$ Laws of Bankers commercial Credits, 6th Edn, 1979, p137.

${ }^{40}$ Benjamin's Sale of Goods [ 1974, para 2074, p 1060]40

${ }^{41}$ [1972-1974] SLR 16 and [1974] 2 All ER 754 PC.

${ }^{42}$ Goode, Roy M, "Reflections on Letters of credit -1 [1980] JBL 291; Professor Goode's article was cited by Stephenson LJ in the Court of Appeal and seems to have influenced the court on the point that a fraudulent bill of lading does not become a conforming document merely because the fraud is that of a third party. With respect the real point is whether under UCP such falsity prevents apparently conforming documents from being accepted in such circumstances. The House of Lord in reversing the Court of Appeal's decision thought not; similar views are held in his book his book Commercial Law, 2nd edn (1995), 1008-1009.

43 (1979) 469 F Supp 473.

${ }^{44}$ See Note 32, supra. 


\section{THE DENNING LAW JOURNAL}

Hick Tin, who broke ranks by allowing the nullity exception in Beam Technologies. ${ }^{45}$

It had also been suggested by others including Schmithorff ${ }^{46}$ a decade before UCP 500 that it would be desirable that the next revision of the UCP should expressly authorise banks to refuse to honour a credit if fraud is established irrespective of whether the seller is party to the fraud. The next UCP [UCP 500] did not heed that advice. Instead the ICC stuck to cases "of which the bank is aware and/or has knowledge or where fraud is proven.” The chorus for revision of the UCP has recently received a boost from Ellinger. ${ }^{47}$

\section{(vi) Banks predicaments credit transactions involving or alleging fraud}

This author, and others in the 'club of the unwilling', has consistently maintained that it is immaterial who commits the fraud, and that what matters is that the bank or seller/beneficiary has knowledge as was so in the American Accord. The guiding principle is "of which the bank is aware and/or has knowledge.” But what constitutes knowledge and/or its extent? Courts do not seem to provide any guidelines. However, as one commentator on the role of credits in money laundering put it, bankers handling letters of credit transactions need to bear in mind that " the legislative history of the money laundering statutes makes clear that knowledge includes the concepts of 'wilful blindness', 'deliberate ignorance', and 'conscience avoidance'. Thus, if a bank employee suspects that someone may be money laundering 'dirty money' but deliberately refuses to ask questions or report the activity to superiors because he wants to remain ignorant, the employee and the bank could be deemed to have knowledge for purposes of assessing criminal liability." 48 Another

${ }^{45}$ By holding that "It is our opinion that the negotiating /confirming bank was not obliged to pay under the LC if it had established within the seven day period prescribed under art 13(b) of the UCP 500, that a material document required under the credit was forged and null and void, and had given notice of its refusal within that period. While we recognise that there could be difficulties in determining under what circumstances a document would be considered material or a nullity, such a question can only be answered on the facts of each case. One cannot generalise. It is not possible to define when a document is a nullity. But it is really not that much more difficult to answer such questions than to determine what is reasonable, an exercise which the courts are all too familiar with.” Beam Technologies, supra, at pp 610-611.

${ }^{46}$ Schmitthoff, Clive M, [1982] JBL 319 at 321.

${ }^{47}$ Ellinger, E P, “The UCP -500:considering a new revision”, LM \& CLQ 2004, pp 3045

${ }^{48}$ Anonymous Author, "UCP and Fraud", supra, at p 217; as to proceeds of drug trafficking see Halsbury's Laws 4th Edition, Vol 11 (1) para 408; as to the powers of the Financial Services Authority to make rules and to institute proceedings see Halsbury's Laws, ibid, Vol 18 (1) paras 38 and 422 respectively; for the powers of the 
commented put it rather crudely that "At the time of sharp market breaks, a bank officer who cannot, at his customer's request discover some plausible reason for dishonouring drafts is hardly worthy of the name." 49 According to this position, "The more prudent approach will be, particularly where the bank's own money is involved, for the bank to carry out its own inquiries to establish the authenticity of the documents which have been presented by the beneficiary." 50

Until that revolution, the position remains that of policy of protecting the credit system. The role and function of the bank in the credit transaction has been supported by Banks LJ in a recent decision of Phillip Brothers Ltd $v$ The Hong Kong and Shanghai Banking Corporation (HSBC), ${ }^{51}$ thus, "The overriding interest of the Courts (is) is maintaining the strength of the letter of credit. To my mind, the Bank primarily takes the commercial risk. The Bank must decide whether the documents conform to its mandate. I would be slow to take that mandate away. If the bank pays it may be unable to be reimbursed. If it does not pay, it runs the risk that its international reputation will be injured. Risk taking is part of the business of the Bank." We shall return to this orthodox and policy-oriented position later. ${ }^{52}$

The American Accord also demonstrates the apparent sharp difference between the liberal and strict interpretations and drew the line between the liberal and strict approach to fraud exceptions.

\section{THE LIBERAL v THE STRICT INTERPRETATION}

\section{(a) The Liberal v the Strict Judicial Approach}

Although the fraud exception on the part of the beneficiary seeking to avail himself of the credit is a clear application of the maxim "ex turpi causa non oritur" or, in plain English, "fraud unravels all", the American Accord has exposed a number of unresolved issues. First, the trial court and the House of Lords should not have allowed court process and the credit to be used for other purposes and by dishonest merchants to carry out fraud. In this respect the case has shown that by adopting the strict approach English courts' attitude towards fraud exception in credit transactions has not been consistent.

Commissioners of Customs and Excise as to offences see Halsbury's Laws, ibid, Vol 12(2) para 1174; and for the Solicitors' duty to report see Halsbury's Laws, Ibid. Vol 37 para 570 and Vol 44 (1) para 90.

${ }^{49}$ Anonymous Author, “UCP and fraud”, supra at p 218.

${ }^{50}$ Ibid.

${ }^{51}$ [1990] 1 All ER 230 (Commercial).

${ }^{52}$ See Part V of this article, post. 
Secondly, some courts, such as the Court of Appeal in this case, take a more liberal approach with regard to the severity of fraud required to justify an injunction in restraint of payment such as the view of Stephenson LJ that, "There was fraud in the transaction, and our courts should adopt the flexible standard to be applied as the circumstances of a particular situation mandate, as did the Uniform Commercial Code (UCC) now ruling in the USA. We should not apply it only to situation...in which wrongdoing of the beneficiary has not vitiated the entire transaction that the legitimate purposes of the independence of the issuer's obligation would no longer be served."53

Thirdly, others favour the more conventional "restricted" approach, as illustrated by Diplock LJ's in the case. In the American Accord, despite the fact that a falsely dated bill of lading was presented under the credit by the beneficiary, because he was unaware of the falsification, the House of Lords felt the bill of lading was good value, presentation was not fraudulent and so the fraud exception did not apply. The 'guilty' knowledge of the seller at the time seems to be the only consideration in deciding whether the presentation is fraudulent or not.

It is submitted that such restrictive approach although simplistic in theory is difficult to apply in practice. It leads to the already demonstrated dilemmas that this puts the banks in. On the one hand, if a bank confronted with fraudulent documents, refuses to pay out, it may be in breach of its obligation to the beneficiary if the documents were forged by a third party. On the other hand, if a bank honours a demand accompanied by documents which to its knowledge are fraudulent, it may be in breach of its obligation to its customer. Consequently, a bank confronted with fraudulent documents will have to work out who committed the fraud before it can decide whether to pay or not. Yet banks are supposed to assume no liability or responsibility for the form, sufficiency, accuracy, genuineness or legal effects of any documents. Furthermore, they are also not supposed to ask any questions and to deal in documents only and not goods.

The American Accord also unavoidably ventured into wider issues of foreign exchange and international finance -the second fraud in the case- issues not covered by any modern English and/or common law decision.

\section{(b) Foreign Exchange Contracts v Sales' Contracts}

Other than the fraud exception, the second point that the court considered was, therefore, whether the contract was an "exchange contract" or a "currency

${ }^{53}$ Cited in, Anonymous Author, "UCP and Fraud”, Journal of Money Laundering Control, supra, at 3. 
transfer contract”, within the context of the Bretton Woods Agreements. ${ }^{54}$ The answer to this preliminary question would determine whether the seller would be allowed to retain the proceeds of the double invoicing involved in the transaction.

However, there were divergence of views between the Court of Appeal on the one hand and the trial court and the House of Lords on the other regarding the constitution of exchange contracts. ${ }^{55}$ By virtue of the Bretton Woods Agreement Order in Council 1946, ${ }^{56}$ made under the Bretton Woods Agreement Act $1945^{57}$ to give effect to the Bretton Woods Agreement: "Exchange contracts which involve the currency ${ }^{58}$ of any Member ${ }^{59}$ and which are contrary to the exchange control regulations ${ }^{60}$ of that member ${ }^{61}$ maintained or imposed consistently with this Agreement ${ }^{62}$ shall be unenforceable ${ }^{63}$ in the territory of the member...."64 It will be apparent later that it is this aspect, rather than enforceability of the sales contract, that influenced their Lordships' decision.

Was the American Accord an exchange or a sales contract? In an earlier decision, Wilson, Smithett \& Co Ltd v Terruzi, Lord Denning said that the term "exchange contract" was not defined, but should be liberally construed having regard to the objects of the Bretton Woods Agreement to protect the currency

${ }^{54}$ Arising from an international conference held at Bretton Woods, New Hampshire, in July 1944 to discuss alternative proposals relating to post-war international payments' problems put forward by the US, Canada and the UK governments. The Agreement resulting from the conference led to the establishment of the IMF and the World Bank.

${ }^{55}$ For Contracts under the Agreement, see Proctor, C Mann on the Legal Aspects of Money, supra, para 1527 pp 385-386.

${ }^{56}$ For the Order in Council see the Bretton Woods Agreement Order in Council 1946, SI No1946/36.

${ }^{57}$ For the Bretton Woods Agreement Act 1945 (as repealed and replaced) see 22 Halsbury's Statutes (3rd edn) p 886.

${ }^{58}$ For the meaning of "Involve the currency", see Proctor, C Mann on the Legal Aspects of Money, supra, para, 1529 pp 398-399.

${ }^{59}$ For the meaning of "Of any member" see, ibid, para 1530 pp 399-400.

${ }^{60}$ For the meaning of "And which is contrary to the exchange control regulations" see, ibid, para $1531 \mathrm{pp} 400-402$.

${ }^{61}$ For the meaning of " Of that member" see, ibid, para $1532 \mathrm{p} 402$.

${ }^{62}$ For the meaning of "Maintained or imposed consistently with this agreement" see, ibid, para 1533 pp 403-405.

${ }^{63}$ For the meaning of "Shall be enforceable" see, ibid, para 1534 pp 405-407.

${ }^{64}$ For an early interpretation of the provision by the Board of Executives of the International Monetary Fund see (1945) 3 ICLQ 262; for "Exchange contracts" see Proctor, Charles, Mann on the Legal Aspects of Money, 6th Edn para 15 28, pp 386398. 
of the states who are parties thereto. He (Lord Denning MR), ${ }^{65}$ considered that, "exchange contract", meant any contracts which in anyway affected a country's

exchange resources. ${ }^{66}$ However, Kerr $\mathrm{J}$ in a detailed judgment rejected Lord Denning's wider (liberal) interpretation and preferred the narrower (restrictive) one of Nussbaum, ${ }^{67}$ namely that "exchange contracts" are contracts to exchange the currency of one country for the currency of another. Interestingly, the Court of Appeal presided over by Lord Denning MR, affirmed Kerr J. One tends to agree with Kerr in this instance that exchange contracts are purely monetary exchange and not sales contracts with elements of currency transfer. Although, Denning overruled himself in the latter case there is some sympathy with his interpretation in the American Accord during its passage through the Court of Appeal that this was an exchange contract disguised as a sales contract.

Subsequently, and for some reason, the court went into detailed discussions on whether this was a sale of goods or sale of documents' contracts. In so doing the Court relied on Kwei Tek Chao (t/a Zung Fu Co) v British Traders and Shippers $L t d .{ }^{68}$ This author has expressed his views on this issue elsewhere. ${ }^{69}$ However, by taking that root in the American Accord the Court of Appeal provided a red-herring and did not add much to the debate: although there is an overlap between the two, the main issue in Kwei Tek Chao was to do with the nature of the CIF rather than credit contracts.

Also cited were analogous English post-war building contract cases and comparative American decisions.

(c) Comparison with English Post-war Building Construction and American Decisions

\section{(i) Comparisons with English Post war Building Construction Decisions}

In arriving at their decision the courts seemed to be persuaded by analogous previous English decisions on building construction contracts. It will be remembered that after the war English courts became familiar with cases in which builders entered into lump sum contracts to do work in excess of amount

${ }^{65}$ Following Mann, FA (see Kerr J in Wilson, Smithett \& Cope Ltd v Terruzzi [1976] 1QB 683 at 698-699.

${ }^{66}$ [1967] 1QB 605, 613 G-4A.

${ }^{67}$ Dr Nussbaum, "Money in the Law-National ands International”, Yale LJ 421 at p 542 et seq.

${ }^{68}$ Kewi Tek Chao (trading as Zung Fu Co) v British Traders and Shippers Ltd [1954] 1 All ER 779.

${ }^{69}$ See generally, Ademun-Odeke, "CIF Contracts-Is it a Sale of Goods or Sale of Documents?” Journal of Contract Law, Butterworths, Sidney, Australia, Vol 6 No 2 1993, pp 158-176. 
for which licences had been granted and so were in breach of Defence (General) Regulations 1939. ${ }^{70}$ In one such case, Jackson Stansfield \& Sons Butterworth ${ }^{71}$ and Dennis \& Co Ltd v Munn, ${ }^{72}$ the plaintiff builders recovered the licensed amount (by concession of the defendant building owners) but could not enforce the claim to the non-licensed excess. Similarly, in Frank W Clifford Ltd $v$ Grath, ${ }^{73}$ the cost in excess of the limit was allowed, although Lord Denning LJ, doubted whether a lump sum contract, "for a single and indivisible work", would not be wholly illegal and irrecoverable. But he concluded they could when the work was divisible into its component items.

Similarly, Stephenson LJ saw no reason why the court should not divide it into its costs and concurred that the court could not be disabled from dividing it by its being claimed in one total; in which case it became a matter of form only. This was compared with a claim for an agreed rent; where the standard rent would be recoverable, whether or not it had been separated in the claim from the excess. ${ }^{74}$ This may be so under English law, but it is not clear whether English common law doctrinal practice should be good examples in international cases. Once more, one cannot see any relevance of these building construction cases other than for purely analogous purposes.

In addition, courts in the American Accord also surveyed a number of comparative American decisions on the subject.

(ii) Comparison with American Decisions and the Uniform Commercial Code (UCC)

In addition to Sztejn, courts in the American Accord referred to a number of other American decisions in relation to a range of issues arising from similar contracts. First, was Old Colony Trust Co v Lawyers' Title and Trust Co, ${ }^{75}$ where the court drew a distinction between a document which was inaccurate and a document which was false, or between a document which was false to the knowledge of its maker and a document which he forged. English courts did not "buy" that argument in the American Accord. Secondly, was Bank of Taiwan $v$ Union National Bank of Philadelphia, ${ }^{76}$ which ruled that if, "The date of the bills of lading did not truthfully represent the date of the beginning of the actual transportation would be a defence, it could constitute a defence if and

${ }^{70}$ SR \& O 1939 No 927, reg 56A.

${ }^{71}$ [1948] 2 All ER 558.

72 [1949] 1All ER 616 2KB 327.

73 [1956] 2 All ER 323.

${ }^{74}$ See Schisselman v Rubin [1951] WN 530.

${ }^{75}$ (1924) 297 F 152.

${ }^{76}$ (1924) 1F 2d 65 at the Circuit Court of Appeals, Third Circuit. 


\section{THE DENNING LAW JOURNAL}

only if the plaintiff knew that fact when it acquired the draft." ${ }^{\text {77 }}$ That case would be no help since the assignee in the American Accord probably did not know the bill of lading was inaccurate. Furthermore, in both the American Accord, and the Bank of Taiwan courts were protecting transferees (banks) not sellers. Thirdly, in Maurice O' Meara Co v National Park Bank of New York, ${ }^{78}$ only the dissenting judgment on a case involving a dispute between a buyer and seller who had misrepresented the security upon which the advance was made was cited. The case did not, however, throw any light on the proceedings and it remains unclear as to why a dissenting judgment was cited except perhaps to provide a link with Bank of East Asia Ltd. V Pang, ${ }^{79}$ a latter case in which the Washington Supreme Court preferred Maurice O'Meara. The other relevance of Bank of East Asia was that it was followed in the leading case of Continental National Bank $v$ National City Bank of New York, ${ }^{80}$ and subsequently in the landmark case of Sztejn. However, those American decisions, especially Sztejn, are distinguishable from the American Accord in that sellers in those cases, by largely shipping rubbish in performance of their contracts, were themselves parties to the fraud.

Fourthly, was Intraworld Industries Inc. Girard Trust Bank, ${ }^{81}$ where the beneficiary's fraud was relevant to the decision. Intraworld was followed in New York Life Insurance Co v Hartford National Bank and Trust $\mathrm{Co}^{82}$ by the Connecticut Supreme Court. Other than that, the New York Life Insurance decision was itself insignificant were it not for citing and following the important United Bank Ltd $v$ Cambridge Sporting Goods Corporation ${ }^{83}$ decision. However, even United Bank Ltd v Cambridge Sports Goods is distinguishable from the American Accord since it represents a number of cases, in the mould of Sztejn, in which the fraud was committed by sellers who shipped rubbish compared to the American Accord where: (a) contractual goods were shipped albeit later than stipulated, (b) the fraud was committed by a third party, and (c) one party with the willing participated of the other sought to use the credit for purposes other than for legitimate sales transactions. It is, therefore, rather difficult to fathom why those American decisions were cited and followed by English courts in the American Accord.

\footnotetext{
77 Ibid at 66.

78 (1925) 239 NY 386 Cardozo’ s.

79 (1926) 249 P 1060.

80 (1934) 69 F 2d 312.

81 (1975) Pa 336 A 2d 313 (beneficiary’s fraud).

82 (1977) 378 A 2d 562).

83 (1976) 392 NYS 2d 265 (old unpadded, ripped and mildewed gloves instead of new boxing gloves).
} 
Fifth, and finally, in the American Accord, the Court of Appeal cited South Western Shipping Corporation v National City Bank of New York ${ }^{84}$ where it was noted that, "all the judges of the court seem to have been of the opinion that the defendant bank could have relied on the rule that the court would not assist a party to an illegal contract to carry out this illegality object, as a defence to the plaintiff's claim in negligence and breach of contract in paying out to the wrong person (in fact the party to the illegal contract) money deposited with the defendant bank in furtherance of a breach of Italian currency [exchange] regulations and art VIII s 2(b) of the Bretton Woods Agreement." ${ }^{85}$ Of the above American decisions cited, this was probably the only one that was all in fours with the American Accord- covering all the 3 issues: (a) fraud in credits, (b) the Bretton Woods Agreement and (c) Exchange Control Regulations of a Member State (Italy).

Following that brief detour the courts in the American Accord returned to other common law doctrine of severance and illegal and unenforceable contracts presumably in order to assistance in solving problems arising from the altered bill of lading and over-invoicing. To determine violation the court had to answer a preliminary question whether the contract in the American Accord was predominantly an exchange contract or a sales contract. It was illegal and should not have been enforced by or in English courts.

\section{COMMON LAW JURISPRUDENCE ON FRAUD EXCEPTION}

\section{(a) Was the Contract Illegal or Unenforceable at Common Law?}

(i) Whether the contract was Illegal or unenforceable

The third and final consideration was as to whether the contract in the American Accord was illegal or simply unenforceable. Apart from the date alteration in the bill of lading the agreement between the buyer and the seller also involved an artificially inflated price in US\$ and a collateral agreement by the seller that it would hold the excess funds as trustee to transmit to the buyer's account in Florida. This latter arrangement was held by the Court of Appeal to be, "a monetary transaction in disguise", and that that part of the credit was therefore unenforceable. The House of Lords concurred that the contract was unenforceable under the 1946 IMF Agreement Order as a monetary transaction in disguise not as a question of construction, but one of looking to the substance of the transaction. ${ }^{86}$

${ }^{84}$ (1959) 6 NY 2d 454, 190 NY 2d 352.

${ }^{85}$ American Accord [1981] 3 All ER 142 at 153.

${ }^{86}$ See Lord Diplock’s decision [1982] 2 All ER at 730 b-d. 


\section{THE DENNING LAW JOURNAL}

In an earlier decision, ${ }^{87}$ Diplock LJ said that the Order made such a contract unenforceable, not illegal. Otherwise under common law illegal contracts are contracts which are forbidden by statute (such as the Bretton Woods Agreement Order in Council) in the instant case or are contrary to common law or public policy and are therefore generally void. Examples are (a) contracts tending to injure the public service, ${ }^{88}$ (b) a contract in restraint of trade, ${ }^{89}$ and (c) a contract to commit a criminal offence or a civil wrong. ${ }^{90}$ Unenforceable contracts, on the other hand, are simply contracts which although valid cannot be enforced directly by action because of some technical defect, e.g., lapse of time. It is submitted that for our purposes these distinctions are academic; for although unenforceable contracts are not necessarily illegal contracts, however, the effect of the two is the same in that the common denominator in both is the unenforceability. The American Accord could not possibly fit into that category-hence the court's willingness to permit severable enforcement of the unoffending part thereof. ${ }^{91}$ It was also doubtful whether it would have made a difference if the contract concerned domestic exchange dealing and exchange control or an external foreign exchange regulation.

(ii) The Legality of Domestic Foreign Exchange Contracts under English Law

From cases cited in the arguments the courts took the position that exchange contracts between citizens and/or residents in the UK are not illegal. $^{92}$ First, in line of these cases, was Sharif $v$ Azad $^{93}$ where the plaintiff a Pakistani citizen resident in the UK claimed against the defendant (another Pakistani citizen) also resident in England, $£ 300$ on a dishonoured cheque for that amount drawn by him on an English bank. The issue arose from the actions of one Latif, a Pakistani resident in Pakistan (but on a visit to England) to take rupees out of Pakistan without the permission of the Pakistan State Bank contrary to Pakistan currency exchange regulations. The defendant's defence

\footnotetext{
${ }^{87}$ Sharif v Azad [1967] 1QB 605, at 618 a-b.

${ }^{88}$ Parkinson $v$ College of Ambulance [1925] 2KB 1 (attempted sale of public office or contract to procure title of honour).

${ }^{89}$ Nordenfelkt v Maxim Nordenfelt Gun Co Ltd [1894]AC 535.

${ }^{90}$ Napier v National Business Agency [1951] 2 All ER 263; see also Howard v Shirlstar Container Transport Ltd [1991] 1WLR 1292.

${ }^{91}$ For "The Legal Character" of Article VIII (2) (b) see Proctor, supra, para 15.0415.08 pp 373-376.

92 For "The Offences created by the 1947 Act " see Proctor, C, ibid, para 14.08-14.14 pp 62-364; and for Personal and Territorial Ambit” see para 14.1, 5 pp 364-5

${ }^{93}$ [1966] 3 All ER 785.
} 
was that the plaintiff had agreed with him to deliver to him rupees' cheque in consideration for the defendant's delivering to the plaintiff the £300 cheque sued on; the object of the transactions, as the plaintiff well knew, was to enable Latif to take money out of Pakistan contrary to Pakistan exchange currency regulations and they were illegal in that they had that illegal object and /or were contrary to public policy.

The court decided that there was nothing illegal in the cheque's transaction in that it took place wholly in England, and found for the plaintiff. Referring to the Bretton Woods Agreements Act 1945 and the Order in Council, Art VIII, s 2(b), the appeal was dismissed. However, there were other background information that swayed the decision in the Sharif and Azad case. The distinguishing factors being, first, that the rupees were placed into a blocked account in Pakistan and not paid to Latif; secondly the action was on a cheque, not a letter of credit. This should be contrasted with Batra $v$ Ebrahim ${ }^{94}$ where it was held, when the point was taken for the first time, that Art. VIII s 2(b) ${ }^{95}$ applied. Accordingly, the two contracts by each of which the plaintiff, an Indian living in England, agreed to pay cheques in sterling to the defendant, another Indian also living in England, and the defendant agreed to pay in exchange Indian rupees in India to him for his benefit when he went to India, contrary to the Indian foreign exchange regulations, where exchange contracts offending against Art VIII s 2(b) are unenforceable in England for that reason.

These two almost identical cases gave rise to contrasting judgments. The only distinguishing factors are that Sharif's decision depended on its special facts. With regard to fraud exception Sharif decision revolved around the law applicable to cheques and should not be applied to credit. So transactions within England in contravention of exchange regulations of a foreign power are not illegal and are therefore unenforceable under English common law. This was not the scenario of the American Accord. In arriving at its decision the courts also provided analogies concerning contracts contravening domestic and foreign legislations.

(iii) Contracts (other than exchange contracts) contrary to domestic English legislation.

In arriving at its judgment the Appeal Court also considered cases in contravention of domestic legislation or other exchange controls or letters of credit. First, in Wilson, Smithett \& Cope Ltd v Terruzzi, ${ }^{96}$ the court decided that contracts for the sale and purchase of metals between brokers on the London

94 [177] Court of Appeal Transcript 197 B.

95 For "The Scope and Interpretation of Article VIII(2)(b)", see Proctor, supra, paras 15.12-15-35 pp 378-407.

96 [1976] 1 All ER 817. 
Metal Exchange and a dealer in Italy, who entered into them in breach of the Italian Exchange Control Regulations, were legitimate sales contracts and, though involving the currency of Italy, were not contracts to exchange one currency for another and were therefore enforceable by the brokers. According, as they were not exchange contracts, Art VIII s 2(b) had no application. Secondly, the Terruzi decision should be contrasted with Ralli Brothers $v$ Compania Naviera Sota y Aznar ${ }^{97}$ where in an allied but distinct principle the courts decided that they would not enforce a contract in a foreign country if performance had become illegal by laws of that country. Aznar involved English chaterers of Spanish shipowners to carry cargo from Calcutta to Barcelona at $£ 50$ per ton; a supervening Spanish Decree put the freight ceiling to 875 pesetas (slightly less than $£ 50$ at the then exchange rate). In a claim by the owners for recovery of the full freight, the court held that they could not recover the excess. Thirdly, in Ragazzoni $v$ K Sethia 1944) Ltd., ${ }^{98}$ the courts refused to enforce a contract for the purchase of jute from India for resale in South Africa when the parties knew that the exporting of jute from India to South Africa was prohibited by Indian law. And finally, in Foster v Driscoll ${ }^{99}$ the court refused any relief to the parties to an agreement to sell whisky in the US in contravention of the prohibition laws.

These decisions are nevertheless distinguishable from the American Accord for a number of reasons. First, although contravening local legislation they were not exchange contracts. Secondly, they did not revolve around letters of credit, although they might have been used for payments therein. Furthermore, the transaction in Ralli Brothers was not illegal $a b$ initio; it only subsequently became so whereas in the American Accord, Sharif and Betram, they were illegal from start. So once again we are not any wiser as to why these cases were cited in the judgment except, perhaps, to demonstrate the difference between contracts in contravention of domestic legislation compared to those against. The courts then moved on another common law doctrine: severability of contracts

\section{(b) On Severability of the Sales and Exchange Contracts}

\section{(i) Application of the Principle of Severability in Contracts}

In reviewing sales contract from exchange contract, the aim in the American Accord was to see whether the legal (goods transaction) part of the contract for which value had been received (sales contract) from the illegal (monetary transactions) part involving transfer of currency for which no value

\footnotetext{
${ }^{97}$ [1920] 2 KB 287.

98 [1957] 3 All ER 286.

99 [1929] 1 KB 470.
} 
had been received (exchange contract). Unfortunately in the process, the courts without any rationale got themselves muddled with the issue of severable contracts. ${ }^{100}$ At common law where a contract is severable, a breach may be found to constitute a default as to only the specific part breached, thus relieving the defaulting party from liability for damages for breach of contract. This is the case both under English and American Law. ${ }^{101}$ However, according to Lord Diplock, above, ${ }^{102}$ it was not strictly accurate to talk of severability in the American Accord. Rather, he thought that the task of the Court was to penetrate any disguise to identify any monetary transactions which the words intended to conceal and to refuse to enforce the contract to the extent that to do so would give effect to the monetary transaction. On this point, the Court of Appeal and the House of Lords both agreed that the seller was entitled to judgment for that part of the relevant instalment (i.e. sales contract) which was not a monetary transaction in disguise. This aspect of the House of Lords judgment is interesting for the following reasons.

First, it provides a clear authority for the narrow or restrictive interpretation of "exchange contract" and the difference in the Anglo-American and European jurisprudence. ${ }^{103}$ Although there is some European support for the wider or liberal interpretation, ${ }^{104}$ the American courts have favoured the narrow approach and this can be justified by the referenced to "currency" rather than "exchange resources" in the Order. ${ }^{105}$ Secondly, the House of Lords uncharacteristically supported Lord Denning's approach in the Terruzzi case of looking to the substance and not the form of the contract-the liberal approach. It will be remembered that this equitable approach was adopted by Lord Denning in reliance on Nussbaum's, ${ }^{106}$ where he referred to "monetary transactions in disguise." Lord Diplock also adopts the phrase but for some reason appears to attribute it to Lord Denning. Thirdly, the House of Lords

${ }^{100}$ For severable contracts at common law see, the case of Nicolene Ltd $v$ Simmonds [1953] 1 QBD 543.

${ }^{101}$ For the US see the Uniform Commercial Code Para 2-612 especially with respect to instalment contracts. See also the case of Sherwood \& Roberts-Yakima, Inc v Cohan, 2 Wash App 703, 469 P2d 574, 578, 582 with respect to severability Clause, Severability Doctrine.

102 See Note 78 supra.

${ }^{103}$ For an early interpretation of this provision by the Executive Board of Director of the IMF see (1954) 3ICLQ 262.

104 See F A Mann, The Legal Aspects of Money, (4th edn) 383 et seq where he cites German cases. However, in a later edition (5th Edn, 1992, Clarendon Press, Oxford) of the book Mann is very critical of the American Accord decision, see p 375.

${ }^{105}$ See Banco Do Brasil, SA v Israel Commodity Co 239 NYS 2d 872, 874 and J Zeevi \& Sons Ltd v Grindlays Bank (Uganda) Ltd 371 NYS 2d 892, 900.

${ }^{106}$ Supra at 427. 


\section{THE DENNING LAW JOURNAL}

adopted what Lord Denning MR said about the meaning of "unenforceable.”107 In that case Lord Denning said that it did not make the contract illegal. He opined that the word should be interpreted to promote the general legislative purpose which here meant that the court itself must take the point. In so doing Lord Denning was continuing his wider interpretation approach for which he was well known.

Fourthly, the House of Lords, like the Court of Appeal, disagreed with Mocatta J, who at the trial stage held that the whole documentary credit was "tarred with same brush." The appellate courts held that only the part of the amount which represented the monetary transaction in disguise was so tainted. This was probably the only ground on which the two upper courts agreed. On the other hand this simply meant that it would not be enforced by the courts but not that it is illegal. Upon this reasoning, the confirming bank could have resisted payment of that part but there was nothing to prevent it under English law from paying out voluntarily. ${ }^{108}$ However, one would go one stage further and suggest, as Mocatta $\mathrm{J}$ did, that the whole contract was tarnished and therefore should have been declared illegal and unenforceable. Lord Denning in the Court of Appeal approached it from this policy perspective. To decide otherwise would have been harsh as it would have deprived sellers for value provided and the assignees (bona fide purchasers or holders in due course). It is probably this consideration, more than anything else that swayed the House of Lords.

This English law approach is different from that of American law and is inconsistent with the principle of the autonomy of the documents to which they had given primacy on the documentary credit front. ${ }^{109}$ In the American case of J Zeevi \& Sons Ltd v Grindlays Bank (Uganda) Ltd., ${ }^{110}$ which does not appear to have been cited, the New York Court of Appeal, adopting the narrow view, held that a letter of credit was not an exchange contract. ${ }^{111}$ It is, however, difficult to see why not. Besides that case was really on discrimination rather than fraud in credit transactions which arguably falls outside the fraud exception rule anyway. Be that as it may, both the trial court and the House of Lords were wrong to delve into these irrelevances and at such length. First, the issues of severance were not pleaded by the plaintiff at the lower levels. Secondly, on the basis of the above arguments it was unnecessary for courts to delve into those issues. It was irrelevant whether severance was applicable because the whole object was to transfer foreign currency in contravention of

\footnotetext{
${ }^{107}$ In an unreported case of Batra $v$ Ebrahim [1977] Court of Appeal Transcript 197B. 108 [1982] 2 All ER at 730 g-h.

109 See American case of Stechy; F.A Mann, supra, at 391.

110371 NYS 2d 892

111 For a strong criticism of the case, see, John S Williams, Cornell LJ, Vol 9 (1975) 239 at p 243.
} 


\section{THE DENNING LAW JOURNAL}

Peruvian Exchange Control Regulations and once that was proved then the claim was untenable. It is not that the doctrine is irrelevant under common law but rather not one to be used, as in this case, to aid the parties. Could the third, and final, doctrine refereed to (equity) be of any use?

\section{Validity of the application of Equitable Doctrine Approach}

In addition to unenforceability for reasons of illegality and the doctrine of severance, all considered, the trial court and the House of Lords were of the view that it would be inequitable to deny the seller and their assignees the benefits of the sales contract portion of the transaction for which goods had been supplied and received by the buyers. The courts asked themselves whether it would be fair and just and in accordance with the rules of equity ${ }^{112}$ to hold otherwise. Thus, the general approach of the two courts seemed to have been more reminiscent of the common law equitable doctrine of severance and would appear to allow the courts more scope than would the common law.

Their Lordships clearly felt that there was no illegality and that as between the parties one was more to blame than the other but that not all should suffer. However, to benefit at equity a party seeking equitable remedy should have "clean hands" and clearly none of the parties (accept perhaps the assignee) in the American Accord had "clean hands" and therefore neither should have benefited from the contract. Although not proven as his act, the seller knew of, and benefited from, the alteration of the date on the bill of lading. It would not be surprising if he had a part in it. On the over invoicing, Stephen LJ lifted the veil, so to speak, above, when he opined that, "the sellers knew exactly what the buyers were up to. They went along with it for no other motives than greed. There was no evidence that there was any undue pressure or duress exerted on them. They did not come forward and if the bank itself had not discovered the fraud the pair of them would have got away with it."113 But then equity is in the realm of the discretion of the judges and cannot be questioned. Thus, although neither of the parties "prayed", the judges had the discretion to raise the matter.

\footnotetext{
${ }^{112}$ Originating from the Latin word aequus meaning fair and encapsulating impartiality and natural justice, it is a body of rules existing by the side of the original civil law, founded on distinct principles and claiming incidentally to supersede the civil law in virtue of a superior sanctity inherent in those principles, and, a system of doctrines and procedures which developed side by side with the common law and statute law , having originated in the doctrines and procedures evolved by the Court of Chancery in its attempts to remedy some of the defects of the common law.
}

${ }^{113}$ [1981] 3 All ER 142. 
The American Accord also dealt with wider trade and financial matters such as over-invoicing in international trade and foreign exchange regulations, thereby confirming its importance in international trade jurisprudence.

\section{FINANCIAL AND POLICY CONSIDERATIONS}

(a) On Over/Under Invoicing and Foreign Currency Exchange Controls
Regulations.

(i) Over-invoicing of imports and under-invoicing of exports and the WTO Agreement.

The American Accord also dealt with some interesting points of private and public international law relating to currency exchange or exchange controls, i.e., domestic legislation placing limits on the holding, trading or other use of foreign currency. ${ }^{114}$ The transaction violated the Peruvian Exchange Control Regulations. By Article 1 of the Peruvian Decree Law 18275 of 15 May 1970, "From the date hereafter it [was] prohibited for individuals or corporations resident in Peru, with the exception of Banco Central de Reserva del Peru and Banco de la Nacion, to maintain or establish deposits in a foreign currency in banks and other institutions in this country and/or abroad.” By Article 18 of the same Law, "it [was] an offence of fraud against the State to maintain foreign currency or to perform any type of operation prohibited by this Decree Law", and more importantly by Article 7 of Decree Law 18891 of 17 June 1971, "The over-valuing of imports and obligations payable in a foreign country, as well as the under-valuing of exports, in violation of what [was] provided for in the Foreign Currency Certificates Regulations, [constituted] the offence of fraud damaging to the State. Any offence referred to in the previous paragraph [was to be] penalised as stated in Article 19 of Decree Law 18275."

First, is the issue of exchange control generally. Exchange controls are often imposed by a government, mostly of developing countries, faced with balance of payments deficits or a currency not easily convertible into other currencies. This is normally achieved by the Central Bank or Finance Ministry

114 Measures are normally taken to ration or prohibit dealings in hard currencies especially in developing countries with balance of payments problems, see Gold, J, The Fund Agreements in Courts 54, and Gold J, The Fund Agreement in Courts, Parts VIII$\mathrm{XI} 43$ et seq. 


\section{THE DENNING LAW JOURNAL}

passing a law regulating foreign currency trading and determining how foreign exchange is spent usually by issuing exchange permits for foreign exchange. Often traders who have either exhausted their quota or are greedy tend to resort to other means, such as over invoicing of imports or under invoicing of exports, to have access to foreign currency. This is made possible by an overseas buyer or seller's collusion. Reasons for control range from stemming an overrun on the economy to petty nationalism.

The general principle of English private international law is that exchange control legislation of a foreign country will be enforced where the object is to protect the economy of that country. The only exception to the principle seems to be where the exchange control in the foreign country is used as an instrument of oppression or discrimination. ${ }^{115}$ Reasons for Peruvian Regulations were neither given nor were they relevant. No oppression or discrimination was pleaded or alleged in the American Accord, thus, it was immaterial. The relief would not be available in that case.

Secondly, is the status of exchange controls under English law. Although the practice is known to common law, it had not come before an English court until this case. Neither had it come altogether in combination with a credit transaction. The principle is founded both in common law, comity and enforcement of international obligations resulting from Agreements, Conventions and Treaties. It will be remembered that the Bretton Woods Agreement which set up the IMF and the World Bank is consistent with both the principle and its exceptions. The courts should have had the courage to deal with it as a new situation. Instead they (the courts) allowed that portion which, in their opinion, did not violate the Peruvian Exchange Control Regulations. The whole transaction should have been disallowed as tainted.

(ii) The meaning of "Oppression" and "Discrimination" in the IMF Agreement and foreign exchange control regulations.

It will be remembered that one of the exceptions to enforcement, by English courts, of foreign exchange controls regulations is where it would be oppressive and their Lordships agreed on the general principles of English private international law that exchange control legislation of a foreign country will be enforced where the object is to protect the economy but not where it is used as an instrument of oppression or discrimination. However, it is not clear what the courts meant by "oppression" and "discrimination" in this respect. Was the aim to stop a State oppressing or discriminating against its own citizens or citizens of another country? A type of national treatment perhaps! There was no guidance from the decision on the nature and extent of the

115 On this point see discussions on the next sub-paragraph immediately below. 


\section{THE DENNING LAW JOURNAL}

subject. However, in ordinary context "oppression”116 and discrimination”117 should be assigned their natural meanings. In legal contexts oppression ${ }^{118}$ and discrimination ${ }^{119}$ mean almost the same. It is, however, unclear whether what the economic meanings of the two terms are.

However, we get the clue from a number of other sources. First, from Mann who says, "Yet it would seem that, although exchange control regulations as a whole may be maintained consistently with the Fund Agreement, certain of their specific effects may be such as to require or permit the refusal to apply them in a given case on the grounds of public policy. This may occur when their application may be discriminatory or penal in character or otherwise obnoxious. There is nothing in the Fund Agreement that would compel the Courts in a given case to reach decisions which are offensive to their sense of justice; they are precluded only from ignoring Member State's exchange control regulations as a matter of principle or of a priori reasoning. It is likely that such is the rationale underlying an important, but not altogether clear, decision of the Dutch Hoge Raad, which rejected Indonesian exchange control regulations. Public policy ought to have been and perhaps was one of the reasons why the New York Court of Appeals in Zeevi v Grindlays Bank disregarded Ugandan exchange control restrictions: 'As typified by strong antiIsrael and anti-semitic suggestions made by Uganda's President to the Secretary General of the United Nations', the Bank of Uganda purported to cancel all payments to Israel companies such as the plaintiffs and the defendant relied on those cancellations, described by the Court as 'confiscatory and discriminatory acts of the Ugandan Government', to avoid liability under an irrevocable letter of credit validly opened before the date of the directive; this surely was contrary to ordre public and could not afford a defence." ${ }^{120}$

${ }^{116}$ From the word to oppress meaning, "to treat with tyrannical cruelty or injustice" Chambers Twentieth Century Dictionary, 1979 Edition p 924 column 2, W\&R Chambers Ltd, Edinburgh.

117 Generally meaning to treat unfairly differently, Ibid at p 369 column 1.

118 "The exercise of authority or power in a burdensome, harsh or wrongful manner, unjust or cruel treatment of subjects, inferiors; the imposition of unreasonable or unjust burdens”: OED Definition adopted in $R$ v Fulling [1987] QB 426. “Oppression includes torture, inhumane or degrading treatment, and the use of or threat of violence (whether or not amounting to torture)": P \& CEA 1984 S 76(8); see also R v Ismail [1990] Crim LR 109; $R$ v Beales [1991] CLR 118

${ }^{119}$ This is the according of some differential treatment to persons or bodies in the same position, eg sex, racial or nationality. Discrimination on the grounds of nationality is prohibited in international by the national treatment principle and in the EU Article 7 of the Treaty of Rome 1957.

${ }^{120}$ Mann, FA, The Legal Aspects of Money (5th Edn, 1992, Clarendon Press Oxford) p 369. In addition to Zeevi case, Mann cites Dallal v Iran and Bank Mellat, Int LR 75, 126, at p 149 where Justice Holtzman quoted this sentence with approval- but cf Dallal 
Secondly, from the WTO Agreement on PSI ${ }^{121}$ which codified the nondiscrimination requirements in its regulations on double invoicing practices which extends obligations to legislate the requirements to importing and exporting countries when implementing the Agreement. ${ }^{122}$ Thirdly, and finally, the Bretton Woods Agreement itself which set up the IMF is also consistent with this principle ${ }^{123}$ of eliminating oppression and discrimination in foreign currency allocations. This was contained in the Bretton Woods Agreement Order in Council $1946^{124}$ made under the Bretton Woods Agreement Act 1945 to give effect to the Bretton Woods Agreement in the UK. to policy considerations.

This article also asserts that on fraud exception in credit transactions the American Accord decision is representative of common law and AngloAmerican jurisprudence approach.

(iii) Policy Considerations in fraud exception decisions

From the above analysis of the American Accord and decisions before and after it, there appears to be no logical conclusions that be drawn. It is submitted that the overriding principle was policy rather than purely legal considerations.

$v$ Bank Mellat, [1986] 1All ER 239, at p 250 where Hobhouse J said that the majority had decided the principle issue 'in somewhat idiosyncratic manner'; Nederlands Tijdschrift vor Internationaal Recht (The Dutch Hoge Raad case), 13 (1966), 69 Int LR 40(1970) 7, where the court said that Art VIII (2)(b) was no obstacle to an assignment in contravention of Indonesian regulations, because Bretton Woods is "intended solely for the regular financial relations between States." Man also thought that "It may well be that the plaintiff in Masouri $v$ Singh, [1986] 1 WLR 1393 could have invoked public policy”, ibid at p 369. This quotation also appear in the 6th Edition of the book, Mann on the Legal Aspects of Money, (2005 Oxford University Press) by Proctor, Charles (Foreword by Mann D (son of Mann FA)) pp 377-378; For "Public Policy under the IMF Agreement” see para15.09-15.13 pp 376-378 (2005 Oxford University Press).

${ }^{121}$ For the WTO Agreement on PSI, see Note 2, supra.

122 "User Members shall ensure that preshipment inspection activities are carried out in a non-discriminatory manner, and that the procedures are criteria employed in the conduct of these activities are objective and are applied on an equal basis to all exporters affected by these activities. They shall ensure uniform performance of inspection by all the inspectors of the preshipment inspection entities contracted or mandated by them"- Non-discrimination, Art. 2(1) of the WTO Agreement on Preshipment Inspection of Goods in International Trade. Other clauses 3(1) on nondiscrimination and Article 1(5-8) and (3(2) on transparency.

${ }^{123}$ Cf. the US Supreme Court case of Kolovrat v Oregon 366 US 187.

${ }^{124}$ Made under the Bretton Woods Agreements Order in Council 1945, s3. 


\section{THE DENNING LAW JOURNAL}

This author has put forward this argument before ${ }^{125}$ that in these cases courts have been more concerned with preserving the basis upon which the letter of credit and therefore international payment system works: the credibility of the banking system. As early as the Sztejn decision in 1941, Shietang J, after citing many cases, gave a glimpse to what was to follow when he said, "It is well established that a letter of credit is independent of the primary contract of sale between the buyer and the seller. The issuing bank agrees to pay upon presentation of documents, not goods. This rule is necessary to preserve the efficacy of the letter of credit as an instrument for the financing of international trade." ${ }^{126}$ Although there are arguments for against policy considerations in judgments, it appears they (the courts) seem to be more concerned with the effect that derogation of such principle, such as the fraud exception, might have. A similar sentiment can be gathered from Jenkins J's statement in Hamza Mallas that, "the opening of a confirmed letter of credit constitutes a bargain between the banker and the vendor of goods which imposes on the banker an absolute obligation to pay, irrespective of any dispute which there may be between the parties on the question whether the goods are up to contract or not. An elaborate commercial system has been built up on the footing that bankers' confirmed credits are of that character, and, in my judgment, it would be wrong for this court in the present case to interfere with the established practice." 127

Megarry J reiterated similar views in Discount Records where he noted that, "I would be slow to interfere with bankers' irrevocable credits and not least in the sphere of international banking, unless a sufficiently grave cause is show: for intervention by the courts that are too ready or too frequent might gravely impair the reliance which, quite properly, is placed on such credits.”128 Similar concern was also expressed by Kerr $J$ in Harbottle where he noted that irrevocable obligations are the "lifeblood of international commerce" 129 and that once the merchants had come to an agreement and had assumed the risk commensurate with the wording of their guarantee, the machinery and commitments of the banks "must be allowed to be honoured, free from interference by the courts. Otherwise, trust in international commerce would be irreparably damaged." ${ }^{130}$ Likewise, in State Trading Corporation of India, Lord Denning MR obiter dictared that, "I may say that performance bonds

\footnotetext{
125 See generally, Ademun-Odeke, “The Judicial Approach to Injunctions in Letters of Credit and Performance Bond Transactions: The Fraud Exception Re-examined”, Denning LJ, 1995, pp 35-65.

${ }^{126}$ Sztejn v J Henry Schroder Banking Corporation (1941) 31 NYS 2d 631 at 634.

${ }^{127}$ Hamza Mallas [1958] 1All ER 262 at p 263.

${ }^{128}$ Discount Records v Barclays Bank [1975] All ER p 1075.

${ }^{129}$ R D Harbottle (Mercantile) Ltd v National Westminster Bank [1977] 2 All ER 862 at 870 .

130 Ibid.
} 
fulfil a most useful role in international trade... The courts must see that these performance bonds are honoured.”131 There have been other dicta and pronouncements on letters of credits and performance bonds (which are treated the same) with or without fraud allegations where courts in refusing relief have stressed the importance of preserving confidence in the credit and bond mechanisms. For instance, in Power Curber International Ltd v National Bank of Kuwait SAK, Lord Denning MR, returned to the theme more emphatically, thus, "If the court of any of the countries should interfere with the obligations of one of its banks (by ordering it not to pay under a letter of credit) it would strike at the very heart of that country's international trade. No foreign seller would supply goods to that country on letters of credit because he could no longer be confident of being paid. No trader would accept a letter of credit issued by a bank of that country if it might be ordered by its courts not to pay." 132 Policy considerations are also used to protect bonafide purchasers or holders in due course as was the case in Discount Records where Lord Denning refused injunctive relief to the applicant since at that time the bill of exchange drawn against the credit will have probably passed to an innocent third party and that if the purpose of the injunction was to deny the seller the proceeds of the fraud, the granting of the injunction would not achieve that objective.

Furthermore it must be remembered that these instruments were developed and used by the banks for their own purpose. If they suffer under their instruments then be it. However, it cannot be forgotten also that in this respect English courts probably have in mind preserving the position of the UK London and as a leading international trade and finance centre and nation, respectively, supported by loyally and obedient judicial, arbitral, shipping and insurance system. It would be unnatural if they didn't.

\section{WIDER IMPLICATIONS OF THE “AMERICAN ACCORD” DECISION}

\section{(a) In the light of the WTO Agreement on PSI}

It would be difficult to determine the possible (alternative) outcome of the American Accord were it to have been decided a decade later following conclusion of the WTO Agreement PSI, to which both the UK and Peru are Parties. $^{133}$

131 State Trading Corporation of India Ltd v E D \& Man (Sugar) [1981] Com LR 235. 132 [1981] 3 All ER 607 at 613.

133 The Agreement deals with over-invoicing and under-invoicing and allows for preshipment inspection of shipment details- essentially price, quantity and, quality of goods ordered overseas. Used by governments of especially developing countries, the purpose is to safeguard national financial interests (prevention of capital flight and 
PSI is important for the countries that participate in it for a number of reasons. It is used: (a) by governments of developing countries to compensate for any inadequacies in the administrative infrastructures; (b) as a way of preventing commercial fraud using shipping, banking or insurance documents; (c) to eliminate customs duty evasions and thereby raising or saving any revenues by the practice of non-declaration or misclassification of goods by eliminating over-invoicing, under-invoicing and; (d) for conservation and avoidance of capital flight by eliminating the practice of over invoicing and under invoicing and to ensure foreign currency is used for essential functions; (e) to provide exporters and importers with extra confidence that the goods match what is specified in the sales; (f) to verify and conform to the rules of origin of the goods; (g) for monitoring of compliance with national regulations; (h) to provide data for statistical purposes; (i) to provide price data for a customs valuation data base; (j) for technical assistance, technology transfer and training; (k) to monitor donor funds and foreign exchange replenishment; (l) to facilitate trade by eliminating delay caused by having to check goods on arrival and the customs process; and (m) to protect consumers.

Defined broadly, ${ }^{134}$ the WTO Agreement PSI has been made mandatory for all importable goods except those exempted by about 40-50 developing countries in Africa, ${ }^{135}$ Asia, ${ }^{136}$ Latin America ${ }^{137}$ and the Caribbean ${ }^{138}$ who use the system to: combat money-laundering, fight against international organised

commercial fraud as well as customs duty evasion, for instance) to compensate for inadequacies in administrative infrastructures-the very objectives that IMF and Peruvian Exchange Regulations sought to promote. Prior to the Agreement no national or international instrument had dealt with the subject.

134 " Pre-shipment inspection activities are all activities relating to the verification of the quality, the quantity, the price, including currency exchange rate and finance terms, and/or the customs classification of goods to be exported to the territory of the user Member” Article 1(3), WTO Agreement on Preshipment Inspections.

135 Angola, Benin, Burkina Faso, Burundi, Cameroon, Central African Republic, Comoros, Cote d'Ivoire, Condo (Democratic Republic), Congo (Republic of ), Equatorial Guinea, Ethiopia, Ghana, Guinea, Kenya, Liberia, Madagascar, Malawi, Mali, Mauritania, Mozambique, Niger, Nigeria, Rwanda, South Africa, Senegal, Sierra Leone, Somalia, Tanzania (excluding Zanzibar), Togo, Uganda, Zambia and Zanzibar( although part of the United Republic of Tanzania which includes the Island of Zanzibar, Zanzibar has separate PSI programmes. Mainland Tanzania has an exclusive contract with COTECNA covering customs, while Zanzibar has one with SGS covering foreign exchange) and Zimbabwe.

${ }^{136}$ Bangladeshi, Cambodia, India, Indonesia, Iran, Philippines and Uzbekistan.

${ }^{137}$ Argentina, Bolivia, Colombia, Ecuador, Mexico, Paraguay, Peru , and Suriname.

${ }^{138}$ Haiti. 
crime and global terrorism. ${ }^{139}$ Thus PSI is now used as a world-wide economic programme for the monitoring of imports into developing countries. It has a positive impact on the national budget, terms of trade, balance of payments and general economic development of the PSI participating countries. For the purposes of the American Accord, objectives (b), (c), (d), (f), (j) and (k) are particularly relevant to this analysis. Major trading nations such as the UK have interest in the success of the Agreement especially in relation to those in the enumerated paragraphs. Therefore, a court ruling such as that of the American Accord today would greatly undermine the WTO Agreement on PSI and developing countries' efforts to restructure their economies and to eliminate money laundering and other types of documentary frauds in international trade. It would provide comfort for money launderers and therefore serve as a Crooks Charter.

\section{(b) Crooks' Charter for Money Laundering and other Documentary Frauds!?}

It is not the aim or intention of this analysis to go into detail on money laundering and related activities. ${ }^{140}$ Rather the argument is that the decision, including those before and after it, except Beam Technologies, would be a crooks' charter for money-launderers. If all that they would incur is the minimum inconvenience arising from severability of contracts then that is a small price to pay. Most money laundering contracts are in fact clothed in the same way as the letter of credit contract. If as in the American Accord, courts are not prepared to confront them they will thrive especially at international financial centres such as London. Retaining London's international position is one thing but making it a soft spot for money launderers is quite another. It has been suggested further that, "International trading companies are known to be one of the high risk business areas which lend themselves more readily to potential criminal activities than others"; ${ }^{141}$ apparently "---because the mechanism of the documentary credit system provides a perfect vehicle for money launderers to launder their criminal proceeds." 142 This would be a natural conclusion since those criminal activities combine the cycle of money laundering itself, placement (cash deposits, wire transfers or other means to place proceeds of crime into accounts of traders/importers/buyers), layering (conversion of cash into letters of credit) and integration (using letter of credit

\footnotetext{
139 Elimination of money-laundering, fight against international organised crime and international terrorism were not among the reasons given for PSI. However, in view of recent developments they would be legitimate additions to the functions of PSI.

${ }^{140}$ For details on Money Laundering and related activities see Note 47, supra.

141 Anonymous Author, Fraud in Documentary Credit Transactions, supra, p 1 142 Ibid.
} 
transactions to disguise the illicit proceeds and allowing the laundered funds to be disbursed back to the criminal or using illicit funds to repay banks for pretrade finance facilities) into one operation.

Like money laundering itself, detailed treatment of white collar crime is also outside the scope of this article. ${ }^{143}$ However, the implications of the decision in the American Accord would clearly provide a licence to violate UK international obligations, such as the IMF and other Agreements, in a number of ways. First, it is of no consequence that such laws are based on common law principles of comity or agreements signed and ratified by the UK. Secondly, it disregards other countries legislation, as in this case the Peruvian Exchange Control Regulations. Thirdly and as constantly argued, in addition to moneylaundering, it would be a license for money launderers to use the letter of credit for such purposes. ${ }^{144}$ By turning a blind eye and deaf ears to these issues, English courts would be abdicating their responsibility to provide judicial supervision. ${ }^{145}$

\section{(c) Abdication of Judicial Supervisory duties}

Despite the crucial role of letters of credit in international trade and finance, courts should not lose their supervisory functions. Shientang J, himself said that, "the principle of the independence of the bank's obligations under the letter of credit should not be extended to protect the unscrupulous seller." This was echoed by the New York Supreme Court decision already cited. ${ }^{147}$ Stephenson LJ also opined that, "But I do not think that the courts have a duty to assist international trade to run smoothly if it is fraudulent any more than when it violates and international agreement. Banks trust beneficiaries to present honest documents; if beneficiaries go to others (as they have to) for the documents they present, it is important to all concerned that those documents should accord not merely with the requirements of the credit but with the facts,

${ }^{143}$ For these and money laundering see generally see Note 47 and 138, supra.

144 In addition to the handicap imposed by the autonomy principle and the independence of documents, art 3(a) and art. 15 of the UCP, the practical problem to the banks is that the documents stipulated under a letter of credit are usually received by the bank from a single source, ie, the beneficiary. These documents may be prepared by the beneficiary himself (such as the inspection certificate in Beams Technologies) and may involve fraudulent situations.

${ }^{145}$ See, John Walker, “How Big is Global Money Laundering”, Journal of Money Laundering Control, Vol No 1 (1999); and generally Wheble, B.S (1993) “Documentary Fraud in International Trade-Whose Fault, Whose Responsibility?” ICC International Maritime Bureau.

146 Sztejn v J Henry Schroder Bank, supra, at p 634.

147 South Western Shipping Corporation v National City Bank of New York (1959) 6 NY 2d 454 . 


\section{THE DENNING LAW JOURNAL}

and if they do not because of the intention of anyone concerned with them to deceive I see no good reason when the choice is between two innocent parties putting the loss on the beneficiary, not the bank or its customer." 148 Griffiths LJ added his views, thus, " The deal ...involved two agreements: first the agreement for the purchase of the machinery, and, second, a collateral agreement by which the Glass Fibres agreed to provide an inflated invoice and to collect dollars on behalf of the Peruvian company through the letter of credit and remit them to the bank in Miami. The sole purpose of the second agreement was to enable the Peruvian company to exchange Peruvian soles for dollars in breach of the Peruvian exchange control regulations; it was the device by which an exchange contract was disguised by inflating the invoice to make it appear all part of the commercial transaction for the purchase of machinery. It was precisely the type of agreement that Professor Nussbaum calls 'monetary transaction in disguise" ${ }^{149}$ and which Lord Denning MR in Wilson $v$ Smithett and Cope Ltd $v$ Terruzi ${ }^{150}$ said would be an exchange contract within art. viii, s 2(b) of the Bretton Woods Agreement and made a part of our own domestic law by the Bretton Woods Agreement Order in Council 1946. His Lordship continued that, “-- but in this case the court is not dealing with a letter of credit that has been opened solely to pay for goods under a sale contract, nor is it dealing with a dispute between buyer and seller under the sale contract. The facts reveal that the buyer and the seller have conspired together to use the letter of credit as a means of giving effect to an exchange contract in breach of the foreign exchange regulations of Peru. Is the court to refuse to recognise the reality of the situation and allow effect to be given to the exchange contract because it sits in blinkers looking at the letter of credit in isolation? I find nothing in any of the decisions dealing with letters of credit that leads to this conclusion. They do no more than establish that the bank is not concerned with possible breaches of the underlying sales contract." ${ }^{151}$ Significantly, and finally the learned Lord Justice was prepared to be bold and gamble by dissenting departure, "I have, after some hesitation, concluded that this case does not bind me to follow a course of action which would, I think, do a grave disservice to the obligations that this country accepted as party to the Bretton Woods Agreement. As Lord Denning MR pointed out in Batra $v$ Ebrahim ${ }^{152}$ [the court itself was under a duty to take the point of unenforceability under the 1946 Order in Council irrespective of the wishes of the parties to the litigation. In my opinion the court should not shirk its duty by turning its back on the reality of the situation. Once it sees that the

\footnotetext{
${ }^{148}$ [1981] 1 All ER at 161.

149 (1949) Yale LJ 421 at 427).

${ }^{150}$ [1976] 1 All ER 817 at 823 , [1976] QB 683 at 714.

151 Ibid .

152 [1977] Court of Appeal Transcript, 197B.
} 
real purpose of the letter of credit is in part to give effect to an exchange contract in breach of the Peruvian exchange control regulations the court should refuse its assistance and decline to give judgment for such part of the claim that relates to the exchange control.”153 Thus, for once a learned judge was prepared to break ranks with the others and with precedence to examine wider views and probably to appreciate the reality of the matter. He was to be joined much later by Justice Chao Hick Tin in Beam Technologies.

\section{(d) Revision of the UCP 500: the UNCITRAL Model and the UCC approaches}

\section{(i) Revision of the UCP}

In addition to the strict interpretation of English and other common law courts on the fraud exception the other problem is failure by the UCP to-date to tackle the problem of fraud head on. It has been suggested in this article that that failure has provided comfort to money launderers, documentary fraudsters and other white collar crimes. There is no provision for fraud in the UCP to balance the autonomy principle contained in article 3 thereon. This and other existing articles do not address or elaborate on the rights and obligations of the various parties involved in the letter of credit transactions in the event of fraud. The doctrine of strict compliance, which is one of the fundamental doctrines in the letter of credit jurisprudence all over the world, is also not elaborated in the UCP 500. The provisions of article 15 exonerating banks from liability or responsibility for the form, sufficiency, accuracy, genuineness, falsification or legal effect of any documents is neither defence nor comfort to them when faced with claims however fraudulent.

The American Accord has demonstrated that the bank may have to pay up even when it knows of fraud so long as it is not committed by the seller or other beneficiary. Yet fraud is a real issue which exists in documentary credit transactions and remains a testing issue for many buyers and their banks caught up in this dilemma. Ellinger ${ }^{154}$ has documented the shortcomings of the UCP 500 in its 13 year life and those of its predecessors. Avoiding the risks of repeating oneself, suffice to point out that among the reforms, the proposals for revision of the UCP, which this author shares, include: (a) improvement of the desired scope of application of the UCP, (b) introduction of a new

\footnotetext{
${ }^{153}$ Ibid. 172.

${ }^{154}$ Ellinger EP “The UCP-500: considering a new revision” LM\&CLQ 2004, pp 30-45; for his earlier contributions see: [1984] LM\&CLQ 578; [1994] LMCLQ 377; The Tender of Fraudulent Documents under Documentary Letters of Credit (1965) 7 Malaya Law Review, 24 at 25-26.
} 


\section{THE DENNING LAW JOURNAL}

classifications of letters of credit according to their tenor rather than the form assumed by the issuing bank's undertakings, (c) strengthening the position of negotiating banks by providing more protections and clarifying the provisions of the UCP, (d) cleaning up the whole areas of autonomy and strict compliance, (e) improving the rejection procedures to give banks more time to examine and investigate with being assumed to have accepted the documents by default, (f) introduction of articles dealing with jurisdiction and the law applicable; and (g) introduction of a provision of arbitration clause and dispute resolutions to say ICC to take the heat out of the courts. It is not the courts duty to formulate any changes. And even if it were, with due respect, courts have developed self importance in themselves to be of any further meaningful changes.

\section{(iii) The UCC Approach}

The second or alternative way out is to adopt the parallel provision of the UCP in the USA, the UCC which provides a more systematic approach to fraud. These are. First, if a presentation is made which appears on its face strictly to comply with the terms and conditions of the credit, but a required document is forged or materially fraudulent, or honour of the presentation would facilitate a material fraud by the beneficiary then (a) the issuer shall honour the presentation, if honour is demanded by (i) a nominated person who has given value in good faith and without notice of forgery or material fraud, (ii) a confirmer who has honoured its confirmation in good faith, (iii) a holder in due course of a draft drawn under the letter of credit which was taken after acceptance by the issuer or nominated person or (iv) an assignee of the issuer's or nominated persons deferred obligation that was taken for value and without notice of forgery or material fraud after the obligation was incurred by the issuer or nominated person, and (b) the issuer, acting in good faith, may honour or dishonour the presentation in any other case.

Secondly, if the applicant claims that a required document is forged or materially fraudulent or that honour of the presentation would facilitate a material fraud by the beneficiary or the issuer or the applicant, a court of competent jurisdiction may temporarily or permanently enjoin the issuer from honouring a presentation or grant a similar relief against the issuer of other persons only if the courts find that (a) the relief is not is not prohibited under the law applicable to an acceptable draft or deferred obligation incurred by the issuer, (b) a beneficiary, issuer, or nominated person who may be adversely affected is adequately protected against loss that it may suffer because the relief is granted, (c) all of the conditions to entitle a person to the relief under the law of this state have been met, and (d) on the basis of the information submitted to the court, the applicant is more likely than not to succeed under its claim of forgery or material fraud and the person demanding honour does not qualify for 


\section{THE DENNING LAW JOURNAL}

protection under subsection (a). However, these approaches would be struck out in English courts as counter to the autonomy principles.

\section{(iv) The UNCTRAL Model Approach}

An alternative is the UNCITRAL model on fraud. The model has two distinct provisions on payment obligations exception (the equivalent of fraud exception) and on court measures. First, on payment obligations exception (equivalent of the UCP fraud exception) Article 19 of the UNCITRAL Convention on the Independent Guarantees and Stand-by Letters of Credit provides as follows. ${ }^{155}$ The UNCITRAL model would be a significant improvement to the solution on fraud. However, as the title suggests these apply only to separate independent guarantees rather than to the general guarantees provide by the issuing bank in credits. Even if it was to come into

155 "(1) If it is manifest and clear that:

(a) Any document is not genuine or has been falsified:

(b) No payment is due on the basis asserted in the demand and supporting documents; or

(c) Judging by the type and purpose of the undertaking, the demand has no conceivable basis, the guarantor/issuer, acting on good faith, has a right, as against the beneficiary, to withhold payment.

(2) For the purpose of subparagraph (c) of paragraph (1) of this article, the following are types of situations in which a demand has no conceivable basis:

(a) The contingency or risk against which the undertaking was designed to secure the beneficiary has undoubtedly not materialised;

(b) The underlying obligation of the principal / applicant has been declared invalid by a court or arbitral tribunal unless the undertaking indicates that such contingency falls within the risk to be covered by the undertaking;

(c) The underlying obligation has undoubtedly been fulfilled to the satisfaction of the beneficiary;

(d) Fulfilment of the underlying obligation has clearly been prevented by wilful misconduct of the beneficiary;

(e) In the case of a demand under a counter-guarantee, the beneficiary of the counter-guarantee has made payment in bad faith as guarantor /issuer of the undertaking to which the counter-guarantee relates.

(3) In the circumstances set out in subparagraphs (a), (b) and (c) of paragraph (1) of this article, the principal/applicant is entitled to provisional court measures in accordance with article 20; cf the ICC Rules 


\section{THE DENNING LAW JOURNAL}

force it would have competition from the tested and tried UCP. There would have to be an express provision to that specifically applicable to and covering credit in the UCP. The long term solution therefore lies with the revision of the UCP

Secondly, the model also provides for provisional court measures include the following provisions. ${ }^{156}$ For the same reasons as in the payment obligations' exception above, this would probably run counter to the autonomy principle as interpreted by English courts.

\section{CONCLUSION}

Beam Technologies has demonstrated that it is perhaps high time English courts reassessed their approach to various aspects of fraud affecting letters of credit and performance bond transactions by revisiting the American Accord, and cases before and subsequent to it. However elaborate the credit contract or the UCP, in the ultimate, though, and regardless of details set out in any standard terms and conditions such as the UCP, the construction of contractual terms remains in the hands of courts. Courts therefore still wield a lot of power which they could use for the good.

First, with regard to the autonomy principle, courts should uphold the principle only in as far as is necessary to facilitate the use of the payment system in international trade. It should not be used as a buffer to protect unscrupulous beneficiaries as was the case in the decisions reviewed hereunder. The application of this principle regardless does not yield unpleasant results but

156 “(1) Where, on an application by the principal/applicant or the instructing party , it is shown that there is a high probability that, with regard to a demand made, or expected to be made, by the beneficiary, one of the circumstances referred to in subparagraph (a), (b), and (c) of paragraph (1) of Article 19 is present, the court, on the basis of immediately available strong evidence, may:

(a) Issue a provisional order to the effect that the beneficiary does not receive payment, including an order that the guarantor /issuer hold the amount of the undertaking, or

(b) Issue a provisional order to the effect that the proceeds of the undertaking paid to the beneficiary are blocked, taking into account whether in the absence of such an order the principal/applicant would be likely to suffer serous harm.

(2) The court when issuing a provisional order referred to in paragraph (1) of this article, may require the person applying therefore to furnish such form of security as the court deems appropriate.

(3) The court may not issue a provisional order of the kind referred to in paragraph (1) of this article based on any objection to payment other than those referred to in subparagraphs (a), (b), and (c) of paragraph (1) article 19 , or use of the undertaking for a criminal purpose." 


\section{THE DENNING LAW JOURNAL}

puts banks in very difficult situations where they are 'damned if they don't pay and are damned if they do'. It is understandable that courts are trying to protection the interest of the third party bona fide purchaser but that desire should be balanced against the equally legitimate interests of the buyer and his bank as other innocent parties. Secondly, courts should not consider the autonomy principle and fraud exception outside other principles such as the doctrine of strict compliance. In the American Accord, the requirements of the doctrine were not fulfilled and, if pleaded, would have protected the buyer and paying bank. The tender of a forged bill of lading did not constitute valid tender under the doctrine of strict compliance. A more liberal approach would have yielded alternative and correct results. Yet the doctrine of strict compliance, which is one of the fundamental doctrines of letters of credit law the world over, is not elaborated in the UCP 500, the only reference being art.13 (a).

Thirdly, regarding the fraud exception it self, courts should not limit the exception to only fraud committed by the seller (although that is the commonest) but should include all frauds affecting the credit. In that context it was un-necessary for the court to delve into common law principles as to whether the contract was severable, illegal or unlawful including the equitable doctrine. Those were distractions from the principal issues. Fourth ${ }_{2}$ courts (especially the House of Lords) should not have abdicated their judicial supervisory responsibilities. In particular they should have provided protection to all concerned parties to the contract. It is the courts' duty to ensure that the letter of credit is not used for purposes other than that for which it was established. It was also imperative on the court to uphold the Bretton Woods system to which this country is Party and has implemented through both a principal and subsidiary legislation. The courts should have been brave and adventurous and should have adopted wider and liberal approach as adopted by Denning LJ, Griffiths LJ and Lane LJ above, as opposed to the narrow and restrictive Diplock LJ approach.

Fifth, the decision has various other implications. One is whether the court would be in position to implement the WTO Agreement on PSI, one of whose aspects deals with over-invoicing in international trade. As a Member State, the UK will no doubt be implementing the Agreement in the near future. As already alluded to, the WTO Agreement on PSI, negotiated in the Uruguay Round, attempts to strike a balance between the concerns expressed by exporting enterprises in developed countries and the need to safeguard the essential interests of developing countries that consider PSI services useful. It is supposed to clarify that its provisions apply to PSI activities carried out in exporting countries, such as the UK, that are contracted or mandated by the governments. Sixth, another implication of the decision is that it would give succour to money laundering, white collar crimes and other documentary 
frauds in international trade. Letters of credit transactions are susceptible to fraud and various money-laundering activities. It will be a pity if a contract partly of sale of goods and partly money-laundering received the same treatment in court as did the American Accord. On the basis and principle of the decision it would not be surprising if the courts sought to separate the unenforceable money laundering aspects from the legitimate sale of goods aspects if such a case came before the court today.

Seventh, and finally, it may be advisable to follow the Singapore decision by adding nullity of the fraudulent documents as an exception to fraud. The approach adopted by the Singapore court (above) was bold, innovative and courageous and merits consideration. Eighth, and finally, it is probably high time that the UCP is amended in its next version to include issues raised herein. In it its current form the UCP is quite contradictory. On the one hand it provides for the rules but on the other hand, by providing for the autonomy and doctrine of strict compliance, it ties the banks' hands. But above all, currently there are no direct and clear provisions for fraud in the UCP. Nevertheless fraud in letters of credit is a real issue. Priority in the amendments should include clear provisions on fraud including the nullity exception. The fraud should be irrespective of which party commits or causes it. This might lead to litigation and a field day for lawyers but it is a small price to pay to protect both parties, for justice and fairness and to fight money laundering and other documentary frauds. 
THE DENNING LAW JOURNAL 